\section{SZEMES Péter}

Somogy Megyei Kaposi Mór Oktató

Kórház

ORCID: 0000-0002-3143-0084

szemespeter1979@gmail.com

\title{
Somlyó György költői indulásáról
}

Somlyó György költővé válása szinte magától értetődő volt, erre tehetsége mellett apai öröksége is predesztinálta. Mindazonáltal mégsem vezetett teljesen egyenes út a sikerig, a szélsőjobboldali támadástól a Nyugat föszerkesztőjének elutasításáig többféle buktató nehezítette indulását.

A tanulmány e kivételes költő pályájának első időszakát veszi górcső alá az inspiráló József Attila-találkozástól Baráth Ferenc ösztönző kritikájáig: „a jövőben kötelessége lesz félredobnia a tengernyi reminiszcenciát, és mankó nélkül saját lábára állnia, saját szellemi talaján!" (Baráth 1939)

Kulcsszavak: Somlyó György, Nyugat

„Én alig tudok életemnek olyan homályos mélyére visszanyúlni, amikor nem sejtettem, sőt nem véltem volna tudni - ha mást nem, hát azt, hogy verseket fogok írni, hogy verseket kell írnom. S ez nemcsak pályaválasztásomat határozta meg, már jóval a pályaválasztás szokott korszakát megelőzve; a választott pálya benső problematikáját, legrejtettebb formai és tartalmi indítékait is sokban meghatározta máig tartó érvénnyel." - olvasható Somlyó 1962-es, Vallomás a költészetről (Somlyó 1980: 42) című írásában. Ezt a sejtelmet és vélelmet az egyéni tehetség mellett az apai örökség erősítette bizonyossággá. Somlyó Zoltán nyugatos útjának követése ugyanakkor nem jelentette az „átkozott költő”, a nagyvárosba szakadt „finom barbár” szerepének átvételét, korán elhallgatott lantja újrahangolását. Sokkal inkább - mint Pomogáts Béla írta - „a hivatást és a költői kifejezés hajlamát" (Pomogáts 2009: 31) kapta tőle, és természetesen személyes ismeretségeket, kapcsolatokat. Elsőként - az atyai íróbarátok (Kosztolányi, Karinthy, Füst Milán, Nagy Lajos, Tersánszky) után - a József Attilával találkozás élményét, akihez diákkori dolgozatát vitték be a Szép Szó szerkesztőségébe. A látogatást már apja halálát követően, 1937 elején megismételte, mikor verseivel, a megformálás mikéntje, az indulás kételyeivel kereste fel a költőt, akitől ezt az útravalót kapta: „Verset az írjon, akinek verset írni könnyebb, mint bármi mást csinálni a világon." (Somlyó 2001: 30) Távozása, mellette persze apjáé és legjobb barátja, Devecseri Gábor öccséé érlelte meg az első közlést, az Újság 1938. január 30-i számában: a Pogány zsoltárolás - József Attila emlékére verset, mely rögtön egy szélsőjobboldali lap éles támadását váltotta ki (Somlyó 2001). Nem véletlenül, hiszen a fiatal alkotó már itt az élet pártjára állt a halállal, a pusztítással szemben, ahogy később egész költészetében is a humánumot védelmezte és erősítette, a szerelem, a szabadság és a kultúra értékeinek felmutatásával (Pomogáts 2009). Mestereit is eszerint választotta: József Attila, illetve William Blake, Paul Valéry és Szabó Lőrinc 
(Somlyó 1980) mellé természetességgel emelkedett az utóbbival közös, Babits Mihály. Mindmegannyi nyelv- és formaművész. Középiskolás versközléseinél (az említett Újságban, a Pesti Naplóban, a Magyar Hírlapban, a Pesti Hírlap Vasárnapjában, de a Szép Szóban is) ezért tartotta fontosabbnak a Nyugat főszerkesztőjének az elutasított kéziratára rótt megjegyzését. Mely csupán ennyiből állt: „Baudelairei hangok: de ez nem pusztán külsődleges hatás. A baudelairei formát belső rokonság indokolja. Csakhogy ez a fajta költészet, ez a páthosz, ez a versforma tisztább és hibátlanabb zengést kívánna." (Somlyó 2001: 49) Illyés bátorításával együtt érett a „lovaggá ütés”, az első nyugatos megjelenés ünnepe, ám a huszadik születésnapot bearanyozó 1940. december 1-i lapszámig hátravolt még a nagy erőpróba: az első kötet.

1939 nyarán, mikor $A$ kor ellen - magánkiadásban - napvilágot látott, már hatályos volt az első, éppen elfogadták a második zsidótörvényt és erősen gyülekeztek a vészterhes, sötét fellegek Európa egén, fújt már a készülő vihar előszele. A mesterei közül Szabó Lőrincnek ajánlott könyv címadó vezérverse az általa eltaposott kis bogár sorsát emeli szimbolikussá, végzettel dacoló kitartását önmaga számára is követendő példává:

„de itt vagyok, s a rámszabott törvénnyel el nem mozdulok, nem rezzenek, körém fonódjék bár millió fojtó hurok. Az egész kor van ellenem! De nincs egy ízem, mely remeg, s büszkén kitárom a hazugság dárdáinak mezítlen mellemet!” (Somlyó 1939: 8)

A Mult, jelen, jövő ciklus nyitánya, az önmegszólító Magamhoz intelmeiben talán atyai parainesis, mesteri tanács nyer megerősítő visszhangot, feltarisznyázva az útnak induló legkisebb fiút. A Sírvers pedig egy újabbal toldja meg őket: az állandóan változó világban a közönyből lesz a legmélyebb fájdalom, csak így érdemes elbúcsúztatni a drága halottakat. Akár örökül kapott, akár olvasmányokból, akár a személyes veszteségek tapasztalatából nyert gondolatfutam, koravén bölcsesség ez egy tizenéves fiatalembertől, melynek gyöngyét mégis szépen zárják magukba a líra kagylóhéjai. Az említett Pogány zsoltárolás még tovább megy, a megoldásig: a tevékeny, műalkotássá formált, megőrző életet állítja szembe a halál erejével. A Magamhoz mellé emelhető Intelem is a szépség, szabadság, igazság, jóság értékeit vallja, szövegének szövetét átszövik a József Attila-allúziók. Ellenpontja a barát, Devecseri Gábornak ajánlott Értékek átértékelése, mely - ahogy a nietzschei cím jelzi - a közösségivel szemben az egyéni, örök helyett a múlandó, Jó helyett a Rossz térhódítását, országlását mutatja be. A Rab lét egyértelműen Babits-hommage, $A$ lírikus epilógjának somlyói párja, az Árnyékban soraiban pedig Szabó Lőrinc bölcseleti lírája visszhangzik. A Furcsa dal a kedveshöz továbblép, a béke- és emberségének a szeretetparancs megvalósítását, az elfeledett örök törvények újratanulását sürgeti, kéri:

„Zengjük fel hát a népet, kiáltsuk:

mindent az emberért!

nélküle meg nem állhat semmi és

semmi semmit nem ér.

Elég már, hogy a semmikért

vesszen az, ami él! 
$(\ldots)$

Éljünk hát önmagunkban, de kiegyenlítve

a bent és odakint

rengő erőket, egymást a távolokon át is

segítve s szeretve mind,

az új, mindent feloldó és megértő

üri közösség szerint." (Somlyó 1939: 22, 25)

Hogy a cikluszáró Mult, jelen, jövőben már csupán a bénító múlttól elvált jelen legyen fényes, a jövő a téboly és gyülölet halálos hálójával kössön meg.

Az Áldozat egység nyitóverse, a Mitosz, a női test jeges tartományának hódítását vizionálja, a Vessz bennem el! zászlótűzése együtt épített új világ, termékenyítő alkotó erő, világrengető akarat megnyerése, míg a Nincs megnyugvás! Szabó Lőrinc-es, vad, kegyetlen, a Másikat szerelemmel maró. A Szerelem négy tételes mikrociklusa is utóbbi színeit használja a Gyötrelem és gyávaság profán triptichonján. Ebben a kedvest gyávaságáért feddi, bátorítja, hogy merjen szabad lenni, feltörni a magasba. A Vihar és felszabadulás a ragyogó fény, a teljesült gyönyör két szonettje. A harmadik tétel, a Faj és egyén, egyszer előbbi érdekét utóbbi célja fölé helyezi, máskor az egyének mindketten célt és eszközt egyaránt magukban rejtenek. A test dicsérete végül, melynek mottóját Nietzschétől vette, a testi szerelem apológiája, s a test múltat és jövőt egyesítő, végtelenséget hordozó erejéé. A Meduza a szakítás, a kegyetlen társtalanság verse, az újraformált közösségé az Áldozat, az egységzáró Híd a beteljesülés utáni, még fájóbb, még szomorúbb magányé:

\author{
„Ó, kénytelenség! örökkévaló \\ megalkuvások! fogcsikorgató \\ tehetetlenség! ó, kimondhatatlan \\ alázatás! Hogy itt csillog köröttem \\ gazdag pompáival a drága város, \\ százezer ház! és millió szoba! \\ És nincsen egy sem, egyetlen kicsiny \\ szobácska, egyetlen kis heverő, \\ ahol öledhez hullhatnék, siratva \\ tizennyolcéves ifjú életem: \\ elvesztett multamat, a meg-nem-értés \\ mocsaraiban elrekedt, hiába- \\ érzett szeretetem, magányba-fúló \\ jelenemet és torz, reménytelen,
} arcomra komorló jövőm!..." (Somlyó 1939: 48)

A Számadás záróciklus darabjaiban a vallomásos jelleg, ismét a személyesség dominál. A 18. születésnapra keletkezett az 1938 november 28 két szonettje. A Kigyulladt élet a világba lépéstől folytonos kínnak, szenvedések sorának láttatja a megtett utat, a Segítsetek! egyetlen hatalmas sikoly, az életet lángra lobbantó, felégető barátokhoz, nőkhöz, oltó oltalomért, szeretetért. A Számadás: két év első öt tétele a kín hitté válását; a sorsosokkal, a szenvedő zsidó néppel, a szenvedő emberiséggel érzett közösséget; a kis örömök megbecsülését; a helyes út keresését; a gondolatok vad táncát villantja fel. A hatodik azonban az apa emlékének szentelt tiszta vallomás: 
„(...) S lényed megérteni tanultam.

S így lettél mégis Te, apám,

ki kiszabtad s megmutattad egyetlen útam:

a mély és elmerült magány

bozótos iszonyú erdejében a korcs, únt,

örök ösvényt, a végzetet:

hogy lássam: minden külső máz alatt a sorsunk

mindig csak egy s közös lehet!" (Somlyó 1939: 60)

A kötetzáró Magány roppant segélykiáltása végül a Segítsetek! párja, könyörgés fényért, szeretetért.

A monográfus Csányi László költői eszközei kifinomultsága miatt csodagyereknek nevezte Somlyót (Csányi 1988), én azonban inkább az idősebb költőtárs, Zalaegerszeg későbbi polgármestere, Baráth Ferenc vélekedését osztom, aki így írt az első könyv kapcsán a Nyugatban: „Somlyó György, Somlyó Zoltánnak vérségi és szellemi fia Szabó Lőrincet vallja mesterének, de el-elkalandozik Baudelaire-ig, azonkívül apja költészetének ízeit is ízlelgeti. Mindenkit egy kis megszorítással követ: Szabó Lőrinc abszolút gondolatiságát a belső perzselés nélkül, Baudelaire fegyelmezett romantikáját a sorok kéjesen sikló tempója nélkül, Somlyó Zoltán tüntető dekadenciáját annak cizellált finomsága nélkül. Nos, mi marad? - Nehéz selymektől, bársonyoktól és könnyű ruhadaraboktól lemeztelenített tehetség, akinek izmai vannak, vére, kemény inai, és ép szellemi csontváza. A kölcsönzött díszruhák fölé egy mindent beburkoló csipkefinom Babits-palást kerül, mely talpától a fejebúbjáig betakarja.

Helyenként mégis csak önmaga szólal meg. Ez a megszólalás ígéret, jel, lehetőség. Kötete: egyéni világnézet, bátor ítélet, majd rezignált fájdalom, igenek és nemek ideges tánca, melynek lendületes mozdulatait letörik az idegen kényszerruhák. Formaérzéke is van: sorai néha szökkenően könnyedek, máskor ércesebbek, tömörebbek - hömpölyögnek.

(...)

Látszik, hogy tud egyéni lenni, ha elfelejt rákacsintani irodalmi eszményképeire. Szabad tér, szabad mozgás kell az ifjú költőnek - s ez kell Somlyó Györgynek is, akinek a jövőben kötelessége lesz félredobnia a tengernyi reminiszcenciát, és mankó nélkül saját lábára állnia, saját szellemi talaján!" (Baráth 1939: 120)

Az első kötet és az említett bemutatkozás az Arcod című verssel a Nyugat 1940. december 1-jei számában mégis költőt avattak, aki erejében bízva, pályatársai, mesterei figyelmétől kísérve indulhatott el útján.

\section{Irodalom}

Baráth Ferenc (1939): Somlyó György: A kor ellen. Nyugat, 31(8), 120

Csányi László (1988): Somlyó György. Bp.: Akadémiai Kiadó

Pomogáts Béla (2009): Arion lantja : Tanulmányok Somlyó György költészetérôl. Bp.: Littera Nova Kiadó

Somlyó György (1939): A kor ellen. Bp.: A szerző kiadása

Somlyó György (2001): Önéletrajzaimból. Bp.: Enciklopédia Kiadó

Somlyó György (1980): Szerelőszőnyeg. Bp.: Szépirodalmi Könyvkiadó 


\section{SUMMARY}

\section{Poetic start of György Somlyó}

It was evident for György Somlyó to become a poet, as he was predestinated for that because of his father's legacy besides his talent. Nevertheless, there was no direct route to success, several pitfalls made his start difficult from an extreme right-wing attack to the rejection of the editor-in-chief of the Nyugat.

The study focuses on the first period of the exceptional poet's poetic career from the inspiring Attila József meeting to Ferenc Baráth's stimulating criticism: „in the future you will be obliged to cast aside the sea of reminiscence, and stand on your own feet without crutches, on your own intellectual ground!" (Baráth 1939)

Keywords: György Somlyó, Nyugat 